DOI 10.18551/rjoas.2019-03.05

\title{
IMPACT OF TRANSFORMATIONAL LEADERSHIP AND COMPENSATION ON INNOVATION BEHAVIOR, WITH EXTRINSIC MOTIVATION AS MEDIATOR
}

\author{
Andika Firmana Tri ${ }^{*}$ \\ School of Business Administration, South China University of Technology, Indonesia \\ Xia Zhou, Professor \\ School of Business Administration, South China University of Technology, China \\ *E-mail: firmanatriandika9@gmail.com
}

\begin{abstract}
An increasingly complex and competitive organization environment, demanding every organization to be more responsive in order to survive and grow. Extrinsic motivation, compensation, transformational leadership is some of factors which is can give impact to the employee innovation behavior. The object for this study is PT. Idefta Nusantara. Population and samples in this study is the employees of PT. Idefta Nusantara. The data used in this research is the data collected from the questionnaire method, which has provided a list of questions by researchers. The data will be processed by path analysis method, using the validity and reliability test and classic assumption test with SPSS version 22 . The results of this study show the hypothesis can prove that the role of transformational leadership and compensation can give effect to innovation behavior through extrinsic motivation as intervening variable; it can be measured by comparing the value of transformational leadership (X1) and compensation (X2) on innovation behavior (Y) directly with the value of its total influence. If the total influence value of each exogenous variable is bigger than its direct influence on the endogenous variable, then the extrinsic motivation can be identified as the intervening variable. Based on the analysis, direct influence of transformational leadership (X1) is 0.231 and compensation (X2) is 0.158 . While total influence of transformational leadership $(\mathrm{X} 1)$ to innovation behavior $(\mathrm{Y})$ is $0,112+0,330=0,442$ and influence of compensation ( $X 2)$ to innovation behavior $(Y)$ is $0,590+0,330=0,920$. From the calculation result showed that the total influence of transformational leadership (X1) and compensation (X2) variables is bigger than the direct influence to the two exogenous variables on innovation behavior $(Y)$. These results indicated that extrinsic motivation $(X 3)$ can be an intervening variable between innovation behavior $(Y)$ with transformational leadership (X1) and compensation (X2). This paper would help leaders in this sector to develop a better understanding.
\end{abstract}

\section{KEY WORDS}

Work environment, transformational leadership, compensation, extrinsic motivation, innovation behavior.

The process of aligning organizational changes with individual changes is not easy. To support such organizational changes, individual changes are required. Leaders are role models in the organization, so change must start from the top level of the leader itself. There are many challenges and obstacles faced by organizational leaders and in leading an organization, the role of leadership will become increasingly difficult (Zaccaro SJ and Klimoski, 2001). Compensation provides an important role for every employee. Compensation can be defined in various ways. In English, "compensation" is defined as something that balances or redeems something else. However, if we look at its origins if words are in different languages, we can get a sense of meaning richness, which combines rights, returns, and rewards (Atul, Matt \& George, 2002). In Chinese, the traditional character for the word "compensation" is based on symbols for wood and water, providing compensation needs in life (Milkovich \& Newman, 2008). In the literature management is 
often used to explain the extrinsic motivation that has something to do with work. The limits of extrinsic motivation can be interpreted as the process by which behavior is driven and directed. The limitation can be interpreted that extrinsic motivation can also be interpreted as a motive situation, so understanding of work motivation is something that raises the spirit or the drive of work.

Normatively, many factors influence innovation behavior, such as motivation, leadership, knowledge management, job satisfaction, competence, compensation and other factors. In this study is limited or emphasized on the relationship of transformational leadership to compensation and innovation behavior with extrinsic motivation as intervening variable, with identification: transformational leadership that must be improved; compensation that must be improved; extrinsic motivation that must be improved; innovation behavior still not maximized.

Empirically, the innovation behavior of individual employees is strongly influenced by many factors, both internal and external factors. The factors of transformational leadership (X1), compensation (X2) and innovation behavior (Y) and extrinsic motivation (X3) are the main variables that become the focus of discussion. Selection of variables in this study as well as the limitations of research. The authors formulate the problems and objectives as follows:

- How does the direct influence of transformational leadership and compensation together on the innovation behavior of employees in the company?

- How does the influence of transformational leadership partially on the innovation behavior of employees in the company?

- How does the effect of compensation partially on the innovation behavior of employees in the company?

- How does the direct influence of transformational leadership and compensation together on employee motivation in the company?

- How does the effect of extrinsic motivation on innovation behavior in company?

- How does indirect influence of transformational leadership and compensation together on innovation behavior in company?

- How does extrinsic motivation play a role as an intervening variable in relation to the influence of transformational leadership and compensation collectively on the innovation behavior of employees in the company?

The benefits as follows:

- Results are expected to provide input to the leadership within the organization in performing appropriate strategies to improve innovation behavior and compensation, especially by using transformational leadership and create employee motivation appropriately;

- Results are expected to complement subsequent research materials in order to increase the knowledge so that it is useful for science, in Human Resource Management, as well as create and or receive the working environment condition as well as possible.

\section{LITERATURE REVIEW}

Transformational Leadership. According to (Geva and Torpey, 2008), leadership is now an important part of science and research, because leadership science is very useful for individuals, jobs and organizations. With the benefits of accessing information today and being used with competitive things, leadership science is fundamental and very important in organizations (Storey, John. 2010).In organizational life, leadership is an important thing, leadership is important to make people in organization behave according to the desired by the leader to achieve organizational goals. A leader is an individual who inspires, motivates, and directs others to achieve their common goals (Yukl GA.1989). According to (Northouse, 2006), transformational leadership is a process that is transforming individual through standards, ethics, and long-term goals. It also includes checking followers' motives, satisfying 
needs, and caring for them. Transformational leadership requires a kind of extraordinary influence that encourages followers to do beyond what is expected of them.

Compensation. (As`ad, 1998), (Dhermawan, Sudibya, Utama, 2012), states that job satisfaction is the result of various work-related attitudes and special factors such as compensation, wages, supervision, job stability, work tranquility, fair work, social relationships in work, and the treatment of superiors. According to (Deluca, 1993) and (Rajkumar, 1996), compensation is defines as pay, reward, remuneration, or salary and wage management. These terms are often used interchangeably in organization. In an organization perspective, compensation is often defines as an important human resource management function where it emphasizes planning, organizing, and controlling various types of pay systems. For example, direct and indirect payments, monetary and nonmonetary rewards and cash and non-cash payments, those compensation is used for rewarding employees who perform in their work or service (Noe, Hollenbeck, Gerhart \& Wright, 2004). In this research, compensation refers to all forms of financial returns and tangible services employees receive as part of employment relationship. It can be seen as a measure of justice. Normally, it is the major source of employees' financial security (Milkovich \& Newman, 2008).

Innovation Behavior. There has been an increasing evidence regarding the role of innovation in the success of the organizations (Martins \& Terblanche, 2003; Patterson et al., 2009). Innovation is viewed as the main determinant of organizational success and competitiveness (Calantone et al, 2002; Neely \& Hii, 1998; Palangkaraya et al, 2010; Salaman \& Storey, 2002; Thornhill, 2006). Recently organizations are paying attention to their human resources to produce innovative behaviors and consequently innovations (Carmeli et al., 2006; Patterson et al., 2009; Scott and Bruce, 1994) because innovations drive from the ideas that come from the individuals in the workplace (Neely \& Hii, 1998; Patterson et al., 2009). Firms depend on their employees with creative ideas and effort (Bharadwaj \& Menon, 2000; Sousa \& Coelho, 2011). Individual innovation behavior in the workplace is considered to be the main pillars of high-performing organizations (Carmeli et al., 2006). Finding out motivators and enablers of individual innovation behavior would be a great contribution toward understanding individual innovation (Carmeli ET al.2006; De Jong, 2006; Wu et al., 2011) and organizational innovation and success (Scott \& Bruce, 1994; Xerri \& Brunetto, 2011).

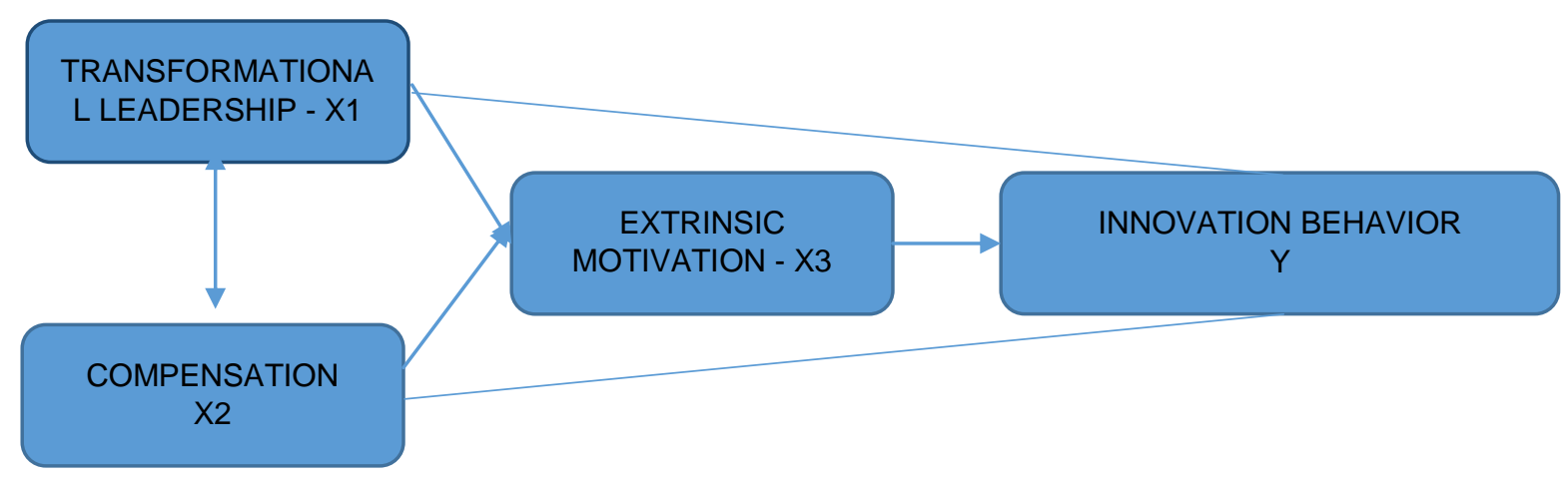

Figure 1 - Framework of study

Extrinsic Motivation. Motivation are the factors that exist within a person that move and direct his or her behavior to meet certain goals. Referring to Abraham $\mathrm{H}$. Maslow's theory of hierarchy, needs that motivation is influenced by the impulse of physiological needs, the impulse of safety needs, the impulse of social needs, the encouragement of appreciation needs, and the impulse of self-actualization needs, while the psychological ability consists of the potential ability (IQ) and the ability of reality (knowledge and skill). (Vroom, V. H. 1964) believe that the work done by employee's aims at a performance that is capable of generating an award. The award may take the form of negative or positive. A positive appreciation will make employees more motivated. The distinction between extrinsic and 
intrinsic was first made popular by Herzberg in 1959, when he divided work rewards into the two different categories (Kanungo \& Hartwick, 1987). When a person is extrinsically motivated the person is driven to perform his or her task because it leads to some separate consequence (Deci \& Ryan, 2008). For a person to be extrinsically motivated then an instrumentality between an activity and some separate reward is required. This means that motivation is drived not from the activity itself, but rather from the extrinsic consequences to which the activity leads (Gagne \& Deci, 2005). In essence "the clearest examples of extrinsically motivated behaviours are those performed to obtain a tangible reward or to avoid a punishment" (Deci \& Ryan, 2008). The tangible rewards here can either be of a financial, material or a social character, all having in common that they originate from the environment.

\section{METHODS OF RESEARCH}

Observation object in this research is PT. Idefta Nusantara. The time of the observation was conducted in November until December 2017.

The research variable is an attribute or the properties or values of a person, object, or activity that has certain variations set by the researcher to study and draw conclusions. In this study, the variables used are Transformational leadership (X1) and Compensation (X2) as independent variables, while Extrinsic motivation (X3) as intervening variable and Innovation behavior (Y) as dependent variable.

Population is defined as the overall subject of the study (Arikunto, 1998). In this study the population is all staff and employees of PT. Idefta Nusantara. In this study the number of samples of 300 employees of PT. Idefta Nusantara. The determination of the number of samples is based on the opinion of (Roscoe, 1975) in (Sekaran, 2000) which states that firstly, sample sizes greater than 30 and less than 500 in most studies are representative. Secondly, if the sample is divided into subsamples, then each category is required at least 30 samples. This method used random sampling that is a group of subjects randomly based on certain characteristics or traits that are considered to have a close relationship with the characteristics of the population. (Polit and Hunger, 1999) define the population as the sum of all subjects appropriate to the research objectives, which comprise the entire group of people interested in the researcher himself, and others whose results can be generalized. According to (Polit \& Hungler, 1999) sampling is the whole population selection process being simpler and can be said to represent the entire population is sampling.

Method of Collecting Data. Data collection using survey method through the distribution of questionnaires to respondents. (Syamsul Hadi, 2006) states that the questionnaire is a set of questions that have been prepared and written before by the researcher, to ask answers to the respondents, the questionnaire is not always a question, but also can be a statement. The process of distributing and collecting questionnaires is done directly in the place of the object of research. The reason for using survey is that researchers can save time, effort, and cost. The use of such methods is also expected to reveal the perceptions of the actual respondents.

Questionnaire is a number of written questions that are used to obtain information from respondents in the sense of reports about his personality or things he knows (Arikunto, 1998). Questionnaires were distributed along with letters of application for questionnaires and explanations of matters relating to the research. The scale used in the questionnaire is the Likert scale with multilevel answers in five categories ranging from highly agreed assessments to highly disagreeable ratings. The Likert scale is used as a basis for making inquiries in this questionnaire, by means of each subject of the study will face statements, and also asked to answer questions that researchers have prepared in the questionnaire. (Umar in Erza, 2012).

Interviews are a means of re-checking or proof of information, data or information that has not been obtained or has been obtained previously. The interview process begins with an introduction that is openly and honestly the researcher introduces himself and explains the purpose of the interview. Researchers put more emphasis on objectivity and honesty that 
is realized by explaining the purpose of research to informants. Preparations that researchers must do before meeting informants is to provide the completeness of the interview and plan what activities need to be done.

Data Instruments Test (Validity and Reliability Test). The accuracy of the use of an instrument must be measured by a validity test (Uys \& Basson, 1991). Validity can be categorized into two types, namely as external and internal validity. In the effort of data processing, the author divides this stage into several parts. First, the indicators / parameters of each variable that are the focus of the discussion are derived in the form of questions / statements in the questionnaire bundle. Questionnaires are compiled using closed models. That is, every question / statement has been provided each answer in the form of Likert scale. Second, the questionnaires distributed and filled by the respondents will be sorted, where each answer will be scored. The value of each score is displayed in matrix form and the total value of the scoring metric will be used as the basis for subsequent data processing that is in the form of statistical computation calculation. Third, the calculation of statistical computation using SPSS software ver 22, where the results of this calculation that will be used as the basis of further analysis.

Validity is defined as a measure of truth or falsity of data obtained through the use of research instruments. These are classified as internal and external validity of measuring tools, (Burns \& Grove, 2001). Validity is a test to determine the accuracy of the status of the measuring instrument in performing the measuring function.

$$
\operatorname{rxy}=\frac{N \sum X Y-\left(\sum X\right)\left(\sum Y\right)}{\sqrt{\left[N \sum X^{2}-\left(\sum X\right)^{2}\right]\left[N \sum Y^{2}-\left(\sum Y\right)^{2}\right.}}
$$

Where: $r x y=$ coefficient of validity of the items observed; $X=$ scores of observed subjects; $Y=$ total score of the observed subjects; $\Sigma \mathrm{x}=$ total score in $\mathrm{X}$ distribution; $\Sigma \mathrm{y}=$ total score in $Y$ distribution; $\Sigma X 2=$ sum of squares in distribution scores $X ; \Sigma Y 2=$ sum of squares in distribution scores $\mathrm{Y} ; \mathrm{N}=$ number of respondents.

The categorization of the validity of the instrument which refers to the classification of validity set forth by (Guilford, 1956) is as follows: $0.80-1.00=$ very high; $0.60-0.80=$ high; $0.40-0.60=$ moderate; $0.20-0.40=$ low; $0.00-0.20=$ very low (not valid).

The degree of consistency in which the instrument measures an attribute is called Reliability (Polit \& Hungler, 1999). The fewer variations of the instrument produced in repeated attribute measurement, the higher the reliability. Invalid instrument can not be relied upon (Polit \& Hungler, 1999). In this research the reliability test is done with the alpha cronbach formula as follows:

$$
r_{n}=\left(\frac{k}{k-1}\right)\left(\frac{\sum \sigma_{b}^{2}}{\sum \sigma_{1}^{2}}\right)
$$

Where: $\mathrm{r} \mathrm{n}=$ Reliability; $\mathrm{k}=$ Number of questions; ${ }^{2}=$ Number of grain variants; ${ }^{2}=$ Total Variant.

The use of Alpha-Cronbach technique will show that an instrument can be said to be reliable if it has a reliability coefficient or alpha of 0.6 or more. Criteria of a research instrument is said to be reliable by using this technique, when the coefficient of reliability is > 0.6 or compared with $r$ table. It is reliable, if the value of Alpha Cronbach coefficient is greater than $r$ table. Categorization which refers to the classification of validity set forth by (Guilford, 1956) is as follows: $0.80<r n<=1.00=$ very high; $0.60<r n<=0.80=$ high; $0.40<r n<=$ $0.60=$ moderate; $0.20<\mathrm{r}<=0.40=$ low; $-1.00<=\mathrm{r} n<=0.20=$ very low (not reliable).

Based on the analytical tools, classical assumptions as follow: 
Data Normality Test. To determine whether in independent variables, dependent variables, and regression models have a normal distribution or not it is very necessary to do this test. By looking at the spread of data then we can detect the normality data regression model. If data distribution forms or follows a diagonal line, then the data distribution regression model can be said to be normal (Ghozali, 2006).

Multicollinearity Test. To test whether the regression model finds correlation between independent variables or not, it is necessary to do multicollinearity test. If there is no correlation between independent variables then the regression model is very good. Variance inflation factor can be use to find out whether there is multicolonierity or can't be seen from the tolerance. The cut off value used to indicate the presence of multicolonierity is a tolerance value $<0.10$ or equal to VIF $>10$ (Ghozali, 2006).

Heteroscedasticity Test. To determine whether in the regression model there is an inequality of variance from one residual observation to another it is necessary to test the heteroscedasticity. If the observed residual variant from one observation remains fixed or homoscedasticity then it is a good regression model. To know heteroscedasticity can be seen from the plot graph, heteroscedasticity can be seen or occurs when the points form a regular pattern: widened, wavy, and narrow. Otherwise heteroscedasticity does not occur when the points spread and do not show a specific pattern (Ghozali, 2006).

Path Analysis. According to (Gujarati, 2003) Path Analysis is an analysis to know the contribution of each variable of variable $x$ to $y$ using regression with variable in standardize. Before testing whether there is any influence, each path is tested for significance. first. If there is a path that is not significant then applied trimming theory that is by eliminating the path that is not significant. Then from the results of the new structure is recalculated each path coefficient.

Based on these results can be known the amount of direct and indirect influence and total influence; then in this research can be formed structural equation as follows:

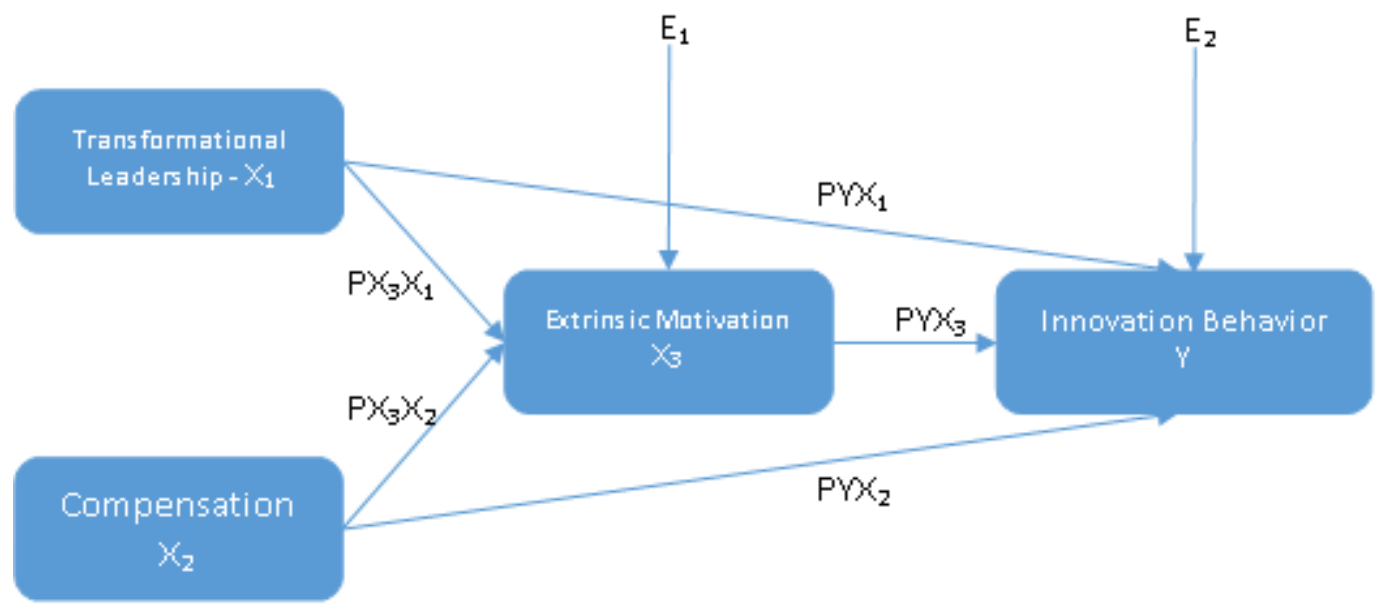

Figure 2 - Path Analysis Model

The empirical causal relationship framework between the selection system and the training program on quality of work through competence can be made through the following structural equations:

Structural equations 1: $\mathrm{Y} 1=\mathrm{PX} 1 \mathrm{X} 3+\mathrm{PX} 2 \mathrm{X} 3+\mathrm{e} 1$

Structural equations 2: $Y 2=P X 1 Y+P X 2 Y+P X 3 Y+e 2$.

Where: $\mathrm{Y}=$ Innovation Behavior; $\mathrm{X} 1$ = Transformational Leadership; $\mathrm{X} 2$ = Compensation; $\mathrm{X} 3$ = Extrinsic Motivation; $\mathrm{P}=$ Coefficient; $\mathrm{e} 1=$ Error of term 1; e2 = Error of term 2.

Hypothesis test. In testing the proposed hypothesis, the researcher uses simultaneous significance test (statistical test $f$ ) and test individual parameters (t test statistic). To see if all independent variables in the model have a simultaneous effect on the dependent variable, it is necessary to do a statistical test $f$. While to see how far the influence of one independent 
variable individually in explaining the dependent variable, it is necessary to do t test statistic (Ghozali, 2005). Tests were performed using a 0.05. The following criteria to show acceptance or rejection of the hypothesis:

- If significant value $>0.05$ means hypothesis is rejected (regression coefficient is not significant). This means that there has no significant effect between independent variable and the dependent variable;

- If significant value $\leq 0.05$ means hypothesis is accepted (significant regression coefficient). This means that the dependent variable gets a significant influence from the independent variable.

The data in this research will be processed by using SPSS version 22 . The hypothesis in this research is influenced by the value of significance of the appropriate variable coefficient after the test. Conclusion The hypothesis is based on t-test and f-test to test the independent variable's significance to the dependent variable.

\section{RESULTS OF STUDY}

Validity and Reliability Test. Validity test using factor analysis techniques, to test whether the grains of questions or indicators used to confirm a factor or a construct or variable. While the reliability test aims to find out how far a measuring instrument can be trusted. Reliability test can be done by using coefficient cronbach's alpha with critical limit for reliable questionnaire value is 0.60 (Soegihartono, 2012).

Table 1 - Reliability Test

\begin{tabular}{|c|c|c|c|c|}
\hline \multicolumn{5}{|c|}{ Reliability Statistics } \\
\hline Factor & $\mathrm{X}_{1}$ & $\mathrm{X}_{2}$ & $\mathrm{X}_{3}$ & $\mathrm{Y}$ \\
\hline Cronbach's Alpha & 0,900 & 0,843 & 0,796 & 0,883 \\
\hline
\end{tabular}

Source: Primary Data.

Normality Test. To see the normalits test is by looking at significant numbers of Kolmogorov-Smirnov test by Kolmogorov-Smirnov test on residual data.

Table 2 - Normality Test

\begin{tabular}{|c|c|c|c|c|}
\hline & & Transformational Leadership & Compensation & Extrinsic Motivation \\
\hline $\mathrm{N}$ & & 300 & 300 & 300 \\
\hline Norm Doromotora,ab & Mean & 30.23 & 20.07 & 11.27 \\
\hline Normal Parameters & Std. Deviation & 3.501 & 2.016 & 1.660 \\
\hline & Absolute & .293 & .188 & .137 \\
\hline Most Extreme Differences & Positive & .129 & .188 & .111 \\
\hline & Negative & -.293 & -.187 & -.137 \\
\hline Kolmogorov-Sm & & 1.605 & 1.032 & .752 \\
\hline Asymp. Sig. (2- & & .012 & .238 & .623 \\
\hline a. Test distribution is Normal & & & & \\
\hline b. Calculated from data. & & & & \\
\hline
\end{tabular}

All variables are normally distributed based on normality test, from KolmogorovSmirnov test significance of 0.012 and 0.238 and 0.623 is greater than $\alpha=0.01$.

Multicollinearity Test. Multicolinearity testing using Variance Inflation Factor (VIF). The VIP value for each independent variable used in the research model is $1.245 ; 1.329 ; 1.076$. this states that the model does not exist or does not occur multicolinearity between independent variables because the value of VIF obtained is smaller than 10. The results can see at table below:

Table 3 - Multicollinearity Test

\begin{tabular}{|c|c|c|c|}
\hline \multicolumn{2}{|c|}{ Model } & \multicolumn{2}{c|}{ Collinearity Statistics } \\
\cline { 3 - 4 } & & Volerance & VIF \\
\hline \multirow{3}{*}{1} & Transformational Leadership & .803 & 1.245 \\
\cline { 2 - 4 } & Compensation & .753 & 1.329 \\
\hline \multicolumn{2}{|c|}{ Extrinsic Motivation } & .929 & 1.076 \\
\hline
\end{tabular}


Heteroscedasticity Test. To determine whether or not heteroscedasticity in this study used Park Gleyser test by correlating the residual absolute value with each independent variable. If the result of probability value has significance value $>$ its alpha value $(0.05)$ then model does not experience heteroscedasticity (Adji Djojo, 2012).

Table 4 - Heteroscedasticity Test

\begin{tabular}{|c|c|c|c|c|c|c|}
\hline \multirow{2}{*}{\multicolumn{2}{|c|}{ Model }} & \multicolumn{2}{|c|}{ Unstandardized Coefficients } & \multirow{2}{*}{$\begin{array}{c}\text { Standardized Coefficients } \\
\text { Beta }\end{array}$} & \multirow{2}{*}{$t$} & \multirow{2}{*}{ Sig. } \\
\hline & & $\mathrm{B}$ & Std. Error & & & \\
\hline \multirow{4}{*}{1} & (Constant) & $-7.994 \mathrm{E}-016$ & 6.882 & & .000 & 1.000 \\
\hline & Transformational Leadership & .000 & .150 & .000 & .000 & 1.000 \\
\hline & Compensation & .000 & .269 & .000 & .000 & 1.000 \\
\hline & Extrinsic Motivation & .000 & .294 & .000 & .000 & 1.000 \\
\hline
\end{tabular}

If the value of probability or significance is less than 0.05 then the model can be said to have no symptoms of heteroscedasticity. The table above shows that the probability or significance level of each variable is 1.000 so it can be ascertained that the model does not experience symptoms of heteroscedasticity, in other words the correlation of each variable with its residual value yields a value greater than its alpha.

Hypothesis Test:

Line Coefficient Calculation in Sub-Structures 1 and 2. The results of the analysis that has been done, then the results obtained from the analysis of Path Analysis can be presented in the following table as follows:

Table 5 - Path Analysis Test

\begin{tabular}{|c|c|c|c|c|}
\hline Equation & Coefficient & $\begin{array}{c}\text { Variable Significance Test } \\
(t \text {-Statistic })\end{array}$ & $\begin{array}{c}\text { Model Test } \\
(F \text {-statistic })\end{array}$ & $R^{2}$ \\
\hline Sub-Structures I & $\mathrm{P}_{3} \mathrm{X}_{1}=0.112$ & 0.504 & 0.003 & 0.413 \\
\hline \multirow{2}{*}{ Sub-Structures II } & $\mathrm{P} \mathrm{X}_{3} \mathrm{X}_{2}=0.180$ & 0.004 & 0.001 & 0.548 \\
& $\mathrm{P} \mathrm{YX}_{1}=0.231$ & 0.000 & 0.001 & \\
\hline
\end{tabular}

Source: Primary Data.

\section{Substructure I:}

- The value of R2 is 0.413 . This value means that the influence of transformational leadership, compensation toward extrinsic motivation together is $41.3 \%$, while the rest equal to $58.7 \%$ influenced by other factor. In other words, the extrinsic motivation variables that can be explained by using transformational leadership variables and compensation are $41.3 \%$, while the effect of $58.7 \%$ is caused by other variables outside the research model.

- Test of significance or testing by using $\mathrm{F}$ test, calculation results with a significance level of $0.05(5 \%)$ by comparing the level of significance (sig). Based on calculation of significance number that is equal to $0.003<0.05$ then $\mathrm{H} 1$ accepted and $\mathrm{Ho}$ is rejected. This means that transformational leadership and compensation with extrinsic motivation have a linear and significant relationship. Conclusion is that transformational leadership style and compensation together influence extrinsic motivation.

- The value of significance (sig) for each variable as follows; transformational leadership is 0.504 and compensation is 0.004 . If the value is compared with $\alpha=0.05$ then only the significance value (sig) has a smaller value compared to 0.05 . In other words, partially from the two exogenous variables of transformational leadership and compensation is only compensation that has a significant relationship to extrinsic motivation while the

- can be seen the value of the beta variable. Where the beta value of transformational leadership variables have no significant relationship to extrinsic motivation. 
- For the magnitude of the influence of each exogoen variable on the extrinsic motivation transformational leadership variables and compensation is 0.112 and 0.590 . Thus it can be seen the results of substructure I is as follows: $\mathrm{X} 3=0.112+$ $0.590+0.587$.

Substructure II:

- The value of R2 is 0.548 . This value means that the influence of transformational leadership, compensation and extrinsic motivation to innovation behavior together is $54.8 \%$, while the rest equal to $45.2 \%$ influenced by other factor. In other words, the innovation behavior variables that can be explained by using transformational leadership variables, compensation and extrinsic motivation are $54.8 \%$, while the effect of $45.2 \%$ is caused by other variables outside the research model.

- Test of significance or testing by using $\mathrm{F}$ test, calculation results with a significance level of $0.05(5 \%)$ by comparing the level of significance (sig). Based on the calculation of significance that is $0.001<0.05$ then $\mathrm{H} 1$ accepted and $\mathrm{Ho}$ is rejected. This means that there is significant relationship between transformational leadership, compensation, innovation behavior, and extrinsic motivation. The conclusion is that transformational leadership, compensation and extrinsic motivation together influence innovation behavior.

- The value of significance (sig) for each variable as follows: transformational leadership is 0.000 , compensation is 0.001 and extrinsic motivation is 0.002 . If the value is compared with $\alpha=0.05$ then the three significance values (sig) of each exogenous variable have a smaller value compared to 0.05 . In other words, partially from the three exogenous variables of transformational leadership, compensation and extrinsic motivation have a linear and significant relationship to innovation behavior.

- For the magnitude of influence of each exogoen variable on the innovation behavior can be seen the value of the beta variable. Where the beta value of transformational leadership variables, compensation and extrinsic motivation is $0.231,0.158$ and 0.330 . Thus it can be seen the results of substructure II is as follows: $Y=0.231+$ $0.158+0.330+0.452$.

In the correlation analysis with SPSS presented:

Table 6 - Intergroup Correlation Results

\begin{tabular}{|c|c|c|c|c|}
\hline \multicolumn{5}{|l|}{ Correlations } \\
\hline & & $\begin{array}{c}\text { Transformational } \\
\text { Leadership }\end{array}$ & Compensation & $\begin{array}{c}\text { Extrinsic } \\
\text { Motivation }\end{array}$ \\
\hline \multirow{3}{*}{$\begin{array}{l}\text { Transformational } \\
\text { Leadership }\end{array}$} & $\begin{array}{l}\text { Pearson } \\
\text { Correlation }\end{array}$ & 1 & $.442^{*}$ & .534 \\
\hline & Sig. (2-tailed) & & .014 & .035 \\
\hline & $\mathrm{N}$ & 300 & 300 & 300 \\
\hline \multirow{3}{*}{ Compensation } & $\begin{array}{l}\text { Pearson } \\
\text { Correlation }\end{array}$ & $.442^{*}$ & 1 & .263 \\
\hline & Sig. (2-tailed) & .014 & & .016 \\
\hline & $\mathrm{N}$ & 300 & 300 & 300 \\
\hline \multirow{3}{*}{ Extrinsic Motivation } & $\begin{array}{l}\text { Pearson } \\
\text { Correlation }\end{array}$ & .534 & .263 & 1 \\
\hline & Sig. (2-tailed) & .035 & .016 & \\
\hline & $\mathrm{N}$ & 300 & 300 & 300 \\
\hline
\end{tabular}

Transformational leadership variables and compensation correlations is 0.442 . Where the correlation of two variables is significant because the value of significance (sig) obtained by $0.014<$ compared with 0.05 . Transformational leadership and compensation correlations on each extrinsic motivation has a value of 0.534 and 0.263 . This suggests that the correlation between the transformational leadership and extrinsic motivation is relatively strong and in the direction of the nature of the significant relationship. This is stated by obtaining a significance value (sig) of 0.035 < compared to 0.05 . Meanwhile, between 
compensation and extrinsic motivation is quite strong and in the direction of the nature of significant relationship. This is stated by obtaining a sig value of $0.016<$ compared to 0.05 .

Result of Influence Calculation. In order to provide an explanation related to the variables studied then the results of influence are made and described in the following table:

Table 7 - Result of Influence Calculation

\begin{tabular}{|c|c|c|}
\hline (Direct Effect) & (Indirect Effect) & (Total Effect) \\
\hline $\begin{aligned} \mathrm{X} 1 & \longrightarrow \mathrm{X} 3 \\
& =0,112\end{aligned}$ & $\begin{array}{l}\mathrm{X} 1 \longrightarrow \mathrm{X} 3 \longrightarrow \mathrm{Y} \\
\mathrm{X}\end{array}$ & $\begin{array}{l}\mathrm{X} 1 \longrightarrow \mathrm{X} 3 \longrightarrow \mathrm{Y} \\
=(0,112+0,330)=0,442\end{array}$ \\
\hline $\begin{aligned} & \mathrm{X} 2 \underset{ }{ } \underset{0,590}{\longrightarrow} \mathrm{X} 3 \\
&\end{aligned}$ & $\begin{array}{c}\mathrm{X} 2 \longrightarrow \mathrm{X} 3 \longrightarrow \mathrm{Y} \\
=(0,590 \times 0,330)=0,1947\end{array}$ & $\begin{array}{l}\mathrm{X} 2 \longrightarrow \mathrm{X} 3 \longrightarrow \mathrm{Y} \\
=(0,590+0,330)=0,920\end{array}$ \\
\hline $\begin{aligned} & X 1 \longrightarrow Y \\
&=0,231\end{aligned}$ & & $\begin{aligned} & \mathrm{X} 1 \longrightarrow \mathrm{Y} \\
&=0,231\end{aligned}$ \\
\hline $\begin{aligned} & X 2 \longrightarrow Y \\
&=0,158\end{aligned}$ & & $\begin{aligned} & X 2 \longrightarrow Y \\
&=0,158\end{aligned}$ \\
\hline $\begin{aligned} \mathrm{X} 3 & \underset{ }{\mathrm{=}} \longrightarrow 0,330\end{aligned}$ & & 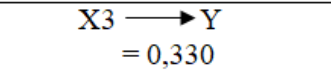 \\
\hline
\end{tabular}

The above calculation results if transformed into image form can be presented as the following chart:

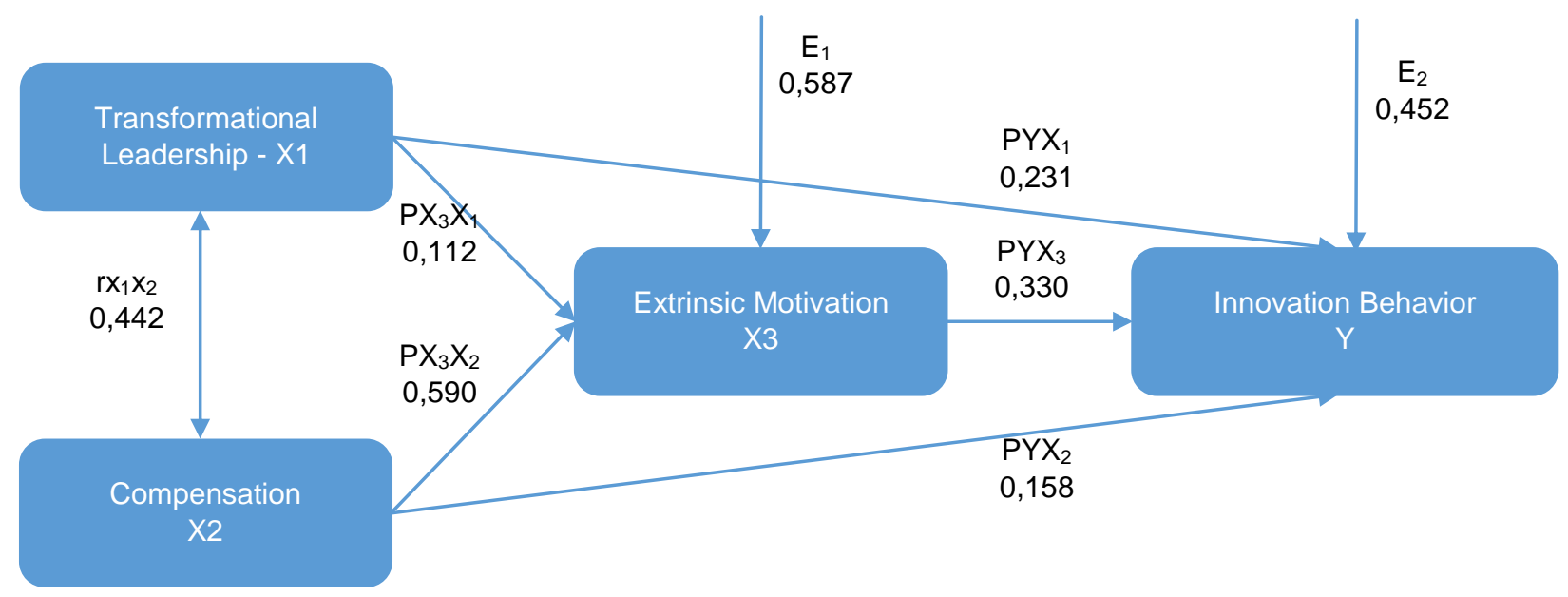

Figure 2 - Causal Relationships between Variables

The hypothesis that alleged that extrinsic motivation (X3) acts as an intervening variable in the influence of transformational leadership factor and compensation on innovation behavior can be proven by comparing the value of transformational leadership factor $(\mathrm{X} 1)$ and compensation $(\mathrm{X} 2)$ on innovation behavior $(\mathrm{Y})$ directly with the value of its total influence. If the total influence value of each exogenous variable is greater than its direct influence on the endogenous variable, then the extrinsic motivation can be identified as the intervening variable. Based on the analysis, the value of direct influence of transformational leadership factor $(X 1)$ is 0.231 and compensation $(X 2)$ is 0.158 . While total influence of transformational leadership $(X 1)$ to innovation behavior $(Y)$ is $0.112+0.330=$ 0.442 and influence of compensation (X2) to innovation behavior $(\mathrm{Y})$ is $0.590+0.330=$ 0.920 . From the calculation result showed that the influence of the total of transformational leadership (X1) and compensation (X2) variables is greater than the direct influence to the two exogenous variables on innovation behavior $(\mathrm{Y})$. These results indicate that extrinsic motivation can play an intervening variable.

\section{REFERENCES}

1. Adji Djojo, Agung. 2012. Aplikasi Praktis SPSS dalam Penelitian, Edisi Kedua. Yogyakarta: Gava Media. 
2. Arikunto, 1998:115. Prosedur Penelitian. PT Rineka Cipta: Jakarta.

3. As`ad, M. 1998. Psikologi Industri. Liberti. Yogyakarta.

4. Soegihartono. 2012. Pengaruh Kepemimpinan Kepuasaan Kerja Terhadap Kinerja denagn Mediasi Komitmen di PT Kayu Sakti Semarang. Jurnal Mitra Ekonomi dan Manajemen. Vol. 3, No. 1, Hal 123-139.

5. Atul Mitra, Matt Bloom, \& George Milkovich, 2002. "Crossing a Raging River: Seeking Far-Reaching Solutions to Global Pay Challenges". World at Work Journal 22.

6. Bharadwaj, S., \& Menon, A. 2000. Making Innovation Happen in Organizations: Individual Crativity Mechanisms, Organizational Creativity Mechanisms or Both. Journal of Product Innovation Management, 17, 424-434.

7. Burns, N \& Grove, SK. 2001. The practice of nursing research: Conduct, critique \& utilization 4th edition. Philadelphia: WB Saunders.

8. Calantone, R. J., Cavusgil, S. T., \& Zhao, Y. 2002. Learning orientation, firm innovation capability, and firm performance. Industrial Marketing Management, 31, 515-524.

9. Carmeli, A., Meitar, R., \& Weisberg, J. 2006. Self-leadership skills and innovative behavior at work. International Journal of Manpower, 27, 75-90. DOI 10.1108/01437720610652853.

10. Deci, Edward L. \& Ryan, Richard M. 2008. Facilitating optimal motivation and psychological wellbeing. Across life's domains. Canadian Psychology/Psychologie canadienne, 49, pp. 14-23.

11. De Jong, J.P.J. 2006. Individual Innovation: The connection between leadership and employees' innovative work behavior. Paper provided by EIM Business and Policy Research in its series Scales Research Reports with number R200604. Retrieved from http://www.entrepreneurship-sme.eu/pdf-ez/R200604.pdf.

12. Deluca, M.J. 1993. Handbook of compensation management. New Jersey, US: PrenticeHall.

13. Dhermawan, Anak Agung Ngurah Bagus, I Gde Adnyana Sudibya, I Wayan Mudiartha Utama. 2012. Pengaruh Motivasi, Lingkungan Kerja, Kompetensi, dan Kompensasi terhadap Kepuasan Kerja dan Kinerja Pegawai di Lingkungan Kantor Dinas Pekerjaan Umum Provinsi Bali. Jurnal Manajemen, Strategi Bisnis, dan Kewirausahaan Vol. 6, No. 2 h 173-184.

14. Gagné, Marylène \& Deci, Edward L. 2005. Self-determination theory and work motivation. Journal of Organizational Behavior, 26(4), pp. 331-362.

15. Geva, D. and Torpey, J. 2008. "Citizenship and military service: questioning the link in a post-Heroic age", paper presented at the annual meeting of the American Sociological Association, Sheraton Boston and the Boston Marriott Copley Place, Boston, MA, 31 July.

16. Ghozali, Imam 2005. Aplikasi Analisis Multivatiate dengan Program SPSS. Semarang: Badan Penerbit Universitas Diponegoro.

17. Ghozali, Imam. 2006. Aplikasi Analisis Multivarite dengan SPSS, Cetakan Keempat, Badan Penerbit Universitas Diponegoro, Semarang.

18. Guilford, J.P. 1956. Psychometric Methods. New York: McGrow-Hill.

19. Gujarati, Damodar, 2003, Ekonometri Dasar. Terjemahan: Sumarno Zain, Jakarta: Erlangga.

20. Kanungo, Rabindra N. \& Hartwick, Jon. 1987. An Alternative to the Intrinsic-Extrinsic Dichotomy of Work Rewards. Journal of Management, 13, pp. 751-766.

21. Martins, E.C., \& Terblanche, F. 2003. Building organisational culture that stimulates creativity and innovation. European Journal of Innovation Management, 6, 64-74.

22. Milkovich G.T. \& Newman, J.M. 2008. Compensation, 9th Ed. McGraw Hill International Edition, USA.

23. Neely, A., \& Hii, J. 1998. Innovation and Business Performance: A Literature Review. Cambridge: The Judge Institute of Management Studies, Retrieved from: http://ecsocman.hse.ru/data/696/521/1221/litreview_innov1.pdf.

24. Noe, R.A., Hollenbeck, J.R., Gerhart, B. \& Wright, P.M. 2004. Fundamentals of human resource management. New York: McGraw- Hill Companies, Inc. 
25. Northouse, P.G. 2006. Leadership: Theory and Practice. Thousand Oaks, CA: Sage Publications.

26. Palangkaraya, A., Stierwald, A., Webster, E., \& Jensen, P. 2010. Examining the Characteristics of Innovative Firms in Australia. A Report for the Australian Government Department of Innovation, Industry, Science and Research, Intellectual Property Research Institute of Australia report, The University of Melbourne.

27. Patterson, F., Kerrin, M., \& Gatto-Roissard, G. 2009. Characteristics and Behaviours of Innovative People in Organisations. Literature Review prepared for the NESTA Policy \& Research Unit, London: NESTA, 1-63.

28. Polit, DF \& Hungler, BP. 1999. Nursing research: Principles and methods. 6th edition.

29. Philadelphia: Lippincott.

30. Rajkumar, K. (1996). Paying for performance: Designing effective compensation strategies. Malaysia: Pelanduk Publications (M) Sdn. Bhd.

31. Roscoe, J.T. 1975. Fundamental Research Statistics for the Behavioural Sciences, 2nd edition. New York: Holt Rinehart \& Winston.

32. Salaman, J.G., \& Storey, J. 2002. Managers' theories about the process of innovation. Journal of Management Studies, 39, 147-165.

33. Scott, S. G., \& Bruce, R. A. 1994. Determinants of Innovative Behavior: A Path Model of Individual Innovation in the Workplace. The Academy of Management Journal, 37, 580607.

34. Sekaran, U. 2000, Research Methods for Business: A Skill-Building Approach. Third Edition. John Wiley \& Sons. Inc. New York.

35. Sousa, C.M. 2011. From Personal Values to Creativity: Evidence from Frontline Service Employees. Highly Commended Award Winner.P. \& Coelho, F. European Journal of Marketing, 45, 1029-1050.

36. Storey, John. 2010. Cultural Studies dan Kajian Budaya Pop: Pengantar Komprehensif Teori dan Metode. Yogyakarta: Jalasutra.

37. Syamsul, Hadi. 2006. Metodologi Penelitian Kuantitatif untuk Akuntansi Keuangan. Yogyakarta; Ekonisia.

38. Thornhill, S. 2006. Knowledge, innovation and firm performance in high-and lowtechnology regimes. Journal of Business Venturing, 21, 687-703.

39. Umar, Husein. 2012. Metode Penelitian Untuk Skripsi dan Tesis Bisnis Edisi 11. Jakarta: PT Raja Grafindo Persada.

40. Uys, H.H.M. \& Basson, A.A. 1991. Research methods in nursing. Pretoria: Educational Publishers (Haum).

41. Vroom, V. H. 1964. Work and motivation. New York: Wiley.

42. Wu, C.H., Parker, S. K., \& De Jong, J.P.J., 2011. Need for Cognition as an Antecedent of Individual Innovation Behavior. Journal of Management.

43. Xerri, M. \& Brunetto, Y. 2011. Fostering the Innovative Behaviour of SME Employees: A Social Capital Perspective, Research and Practice in Human Resource Management, 19, 43-59.

44. Yukl GA.1989. Leadership in Organizations 2nd Ed. Englewood Cliffs, NJ: Prentice-Hall.

45. Zaccaro SJ, Klimoski RJ. 2001. The nature of organizational leadership: Understanding the performance imperatives confronting today's leaders. San Francisco: Jossey-Bass. 